\title{
BENTUK POLITIK UANG PADA PILKADA PROVINSI BENGKULU TAHUN 2015
}

\section{THE FORM OF MONEY POLITICS IN THE BENGKULU PROVINCE ELECTION OF 2015}

\author{
Dede Suprianto ${ }^{1}$, Titin Purwaningsih ${ }^{2}$, Zaldi Rusnaedy $\mathbf{S}^{\mathbf{3}}$ \\ 1Magister Ilmu Pemerintahan Universitas Muhammadiyah Yogyakarta \\ 2Ilmu Pemerintahan UMY Universitas Muhammadiyah Yogyakarta \\ 3Ilmu Pemerintahan Universitas Pancasakti Makassar \\ E-mail: suprianto.ms.dede@gmail.com
}

\begin{abstract}
This article describes money politics that occurred in the election in Bengkulu Province in 2015. The method used in this study is qualitative, using data collection techniques namely interviews and documentation. Whereas the target of this research is Bawaslu, KPUD and the Success Team. The results of this study indicate that the form of money politics consists of vote buying as many as 33 cases, vote trading as many as 2 cases and club goods in 1 case. All of these reports were not followed up because they did not meet the formal and material requirements and expired, due to the Singaran Pati PPK case which was sued by the Sultan-Mujiono pair to the Constitutional Court. Although the Constitutional Court finally rejected the claim based on consideration of the vote threshold between the applicant and the winner of the most votes with a difference between the two by $14 \%$.
\end{abstract}

Keywords: money politics, a form of money politics, local election

\begin{abstract}
ABSTRAK
Artikel ini menjelaskan tentang politik uang yang terjadi pada Pilkada di Provinsi Bengkulu tahun 2015. Metode yang digunakan dalam penelitian ini adalah kualitatif, dengan menggunakan teknik pengumpulan data yaitu wawancara dan dokumentasi. Sedangkan yang menjadi sasaran penelitian ini adalah Bawaslu, KPUD dan Tim Sukses. Hasil penelitian ini menunjukkan bahwa bentuk politik uang terdiri dari vote buying sebanyak 33 kasus, vote trading sebanyak 2 kasus dan club goods sebanyak 1 kasus. Semua laporan tersebut tidak ditindaklanjuti karena tidak memenuhi syarat formal dan materil serta kedaluwarsa, kecuai kasus PPK Singaran Pati yang digugat pasangan SultanMujiono ke Mahkamah Konstitsi. Meskipun MK akhirnya menolak gugatan tersebut berdasarkan pertimbangan ambang batas suara antara pemohon dan peraih suara terbanyak dengan selisih diantara keduanya sebesar 14\%.
\end{abstract}

Journal of Governance and Local Politics (JGLP)

ISSN (online): 2684-9992, Vol: 1, Nomor: 1, Mei 2019 


\section{Kata kunci: politik uang, bentuk politik uang, Pilkada}

\section{PENDAHULUAN}

Momentum politik elektoral seperti Pilkada, di masyarakat beredar dua istilah yang patut dicermati, yaitu uang politik dan politik uang. Kedua istilah tersebut secara sekilas sama namun memiliki perbedaan makna. Uang politik adalah uang yang digunakan secara wajar untuk mendukung kegiatan operasional yang akan dilakukan dalam kontestasi Pilkada. Contoh dari uang politik diantaranya biaya administrasi pendaftaran pasangan kandidat, biaya operasional kampanye pasangan kandidat, dan lain-lain. Sedangkan politik uang ialah yang ditujukan untuk maksud-maksud tertentu, entahkah itu dalam Pemilu atau dalam hal-hal lain yang berhubungan dengan keputusan-keputusan penting. Politik uang dapat terjadi ketika kandidat membeli dukungan partai politik atau membeli suara dari pemilih untuk memilihnya dengan imbalan materi (Zaman, 2016 dan Nasution, 2013).

Faktor penyebab terjadinya politik uang dalam Pilkada sebagaimana yang diteliti Azhari (2012) diantaranya adalah lemahnya penegakan hukum dan meyusutnya moralitas, lemahnya peran partai sebagai lembaga pendidikan politik, dan fenomena kemiskinan. Nasution (2013) yang memfokuskan penelitiannya pada keterakitan antara daerah yang berkembang menjadi tempat tumbuh suburnya politik uang. Dari fenomena tersebut, politik uang punya kaitan yang erat dengan kemiskinan.

Bentuk dari politik uang menurut Lesmana sebagaimana dikutip Zaman (2016) bisa berupa uang namun bisa pula berupa bantuan-bantuan sarana fisik berupa kampanye pasangan kandidat tertentu. Pengertian ini menggambarkan politik uang sebagai strategi jual beli suara pada proses politik dan kekuasaan serta tindakan membagi-bagikan uang untuk memengaruhi suara pemilih. Praktik politik uang dalam Pilkada secara langsung menunjukkan 
kecenderungan makin menguat sebagaimana dilaporkan oleh sejumlah lembaga survei, seperti temuan oleh ICW menunujukan besaran politik uang nasional dalam Pilkada 2010 lebih besar daripada Pilkada 2005 dan temuan servei LSI pada 2010 menunjukan bahwa frekuensi praktik politik uang meningkat 11,9\% dibandingkan Pilkada 2005 yang hanya 8,9\%. Sedangkan dalam Pilkada serentak Pilkada 2015 terdapat 910 kasus politik uang yang tersebar hampir merata seluruh Indonesia yang menggelar Pilkada serentak 2015. Tetapi, 846 laporan praktik politik uang dalam Pilkada dihentikan prosesnya. Praktik politik uang itu sebanyak 829 berupa pemberian uang kepada pemilih dan kasus pembagian barang sebanyak 81 kasus (Zaman, 2016).

Sebaran praktik politik uang di atas dalam pandangan Kumorotomo (2009) bahwa agak sulit untuk memperoleh data faktual mengenai besarnya uang yang berseliweran selama masa Pilkada, tetapi setiap orang akan tahu bahwa kasus-kasus politik uang merupakan hal yang jamak dalam perhelatan Pilkada setelah reformasi. Kendatipun semua calon jika ditanya akan selalu mengatakan bahwa mereka tidak terlibat dalam politik uang. Massifnya praktik politik uang dalam Pilkada sebagaimana yang telah diuraikan di atas tersebar hampir seluruh daerah di Indonesia, tidak terkecuali Provinsi Bengkulu yang menjadi lokasi dari penelitian ini. Pada pemilihan Gubernur tahun 2015 di Provinsi Bengkulu, terdapat dua pasang calon yang ikut dalam kontestasi tersebut.

Pada Pilkada tersebut, pasangan calon Ridwan Mukti dan Rohidin Mersyah dinilai terbukti melakukan praktik politik uang. Mereka diduga telah memberi uang sebesar Rp 5 juta kepada anggota Panitia Pemilihan Kecamatan (PPK) Singaran Pati, bernama Ahmad Ahyan yang telah dijatuhi sanksi pemberhentian tetap oleh Dewan Kehormatan Penyelenggara Pemilu (DKPP) (JJPN.com, 2016). Dugaan politik uang ini bukan hanya sekali dilakukan oleh pasangan Ridwan-Rohidin, dan terbukti. Pasalnya, dalam masa kampanye juga 
tim paslon tersebut juga diketahui secara langsung membagikan peralatan elektronik seperti kulkas, mesin cuci, hingga sepeda motor yang nyata-nyata melanggar ketentuan dana kampanye (Republika.co.id 2016).

Karena politik uang merupakan perkara yang amat merusak, UndangUndang nomor 8 Tahun 2015 telah mengatur prosedur penanganan politik uang secara rinci. Meskipun peraturan mengenai politik uang dan sanksinya agar bisa memberikan efek jera masih banyak menyisakan kelemahan dan celah hukum. Politik uang tidak hanya massif, tetapi juga sudah sangat terbuka, hingga Pilkada berakhir belum terdengar para pelaku politik uang yang diajatuhkan sanksi (Zaman, 2016) termasuk pasangan calon Ridwan Mukti dan Rohidin Mersyah.

\section{METODE PENELITIAN}

Artikel ini berangkat dari hasil penelitian yang menggunakan pendekatan penelitian kualitatif. Pendekatan penelitian kualitatif bermaksud untuk memahami tentang apa yang dialami oleh subjek penelitian dengan cara deskripsi dalam bentuk kata-kata dan bahasa dengan memanfaatkan berbagai metode alamiah (Moleong, 2007). Sasaran dari penelitian ini adalah Bawaslu dan tim sukses kandidat. Teknik pengumpulan data yang digunakan yaitu dokumentasi dan wawancara. Studi dokumentasi dilakukan terkait data praktik politik uang, sedangkan wawancara komisioner Bawaslu Provinsi Bengkulu dan tim sukses kandidat.

\section{HASIL DAN DISKUSI}

Pada saat Pemilihan Gubernur Provinsi Bengkulu, penggunaan uang dan barang sebagai alat tukar untuk mendapatkan suara pemilih masih sangat mendominasi. Berdasarkan data Bawaslu Provinsi Bengkulu, penyebaran praktik politik uang terdiri dari berbagai varian mulai dari tim Ridwan MuktiRohidin Mersyah, Sultan Najamuddin-Mujiono hingga penyelenggara Pemilu 
sebagai terlapor pelaku politik uang.

Di bawah ini akan diklasifikasikan pelaku politik uang yang secara sederhana terbagi menjadi empat bagian. Yaitu dari pelaksana Pemilu, tim Ridwan-Rohidin, tim Sultan Najamuddin-Mujiono, dan terlapor yang tidak diketahui identitasnya. Sebagaimana data yang didapatkan di Bawaslu Provinsi Bengkulu, dari pihak Ridwan-Rohidin sebanyak 23 kasus terlapor, dari pihak Sultan-Mujiono sebanyak 2 kasus terlapor, sedangkan pihak terlapor yang tidak diketaui sebanyak 9 laporan dan penyelenggara sebanyak 2 terlapor.

Banyaknya laporan terhadap pasangan Ridwan-Rohidin yang notabenenya pemenang Pilkada. Laporan penggunaan politik uang secara massif dilaporkan ke Bawaslu setelah pemungutan suara dilaksanakan. Fenomena tersebut menjadi bukti kuat bahwa pelaporan praktik politik uang akan dilaporkan setelah ada hasil menang atau kalah. Dilihat dari tanggal pelaporan politik uang oleh terlapor pasangan Ridwan-Rohidin semuanya setelah rekapitulasi penghitungan suara pemilihan di tingkat provinsi tanggal 18 Desember 2015.

\section{Bentuk Politik Uang: Vote Buying, Vote Trading, dan Club Goods Dinamika Vote Buying}

Transaksi antara pemilik suara dengan calon atau vote buying secara sederhana terbagi dalam dua bentuk yaitu dalam bentuk uang dan barang. Kedua bentuk vote buying ini merupakan modus yang paling banyak dilakukan pada Pilkada Provinsi Bengkulu. Dalam studi ini pemberian imbalan materi kepada masyarakat yang memiliki hak pilih dibagikan menjelang pemungutan suara. Secara umum, yang menjadi target politik uang biasanya pemilih yang sudah menjadi basis pendukungnya atau bisa juga dalam waktu menjelang hariH pencoblosan yang dibagikan secara sporadis. Di bawah ini akan diuraikan bentuk vote buying baik dalam bentuk uang ataupun barang.

Uang merupakan alat pertukaran suara antara calon dan pemilih yang 
paling sering digunakan. Dalam Pilkada Provinsi Bengkulu, uang merupakan modal utama yang dimiliki kandidat untuk mendapatkan suara dari pemilih. Pemilihan uang sebagai transaksi pertukaran dengan dengan suara pemilih berdasarkan pengalaman pada pemilihan-pemilihan sebelumnya juga berdasarkan pengalaman pemilihan di daerah lain.

Berdasarkan temuan di atas, vote buying dalam bentuk uang sebanyak 14 temuan dari 36 praktik politik uang. Nominal pembagian uang bervariasi kepada pemilih mulai dari 20 ribu hingga yang paling tertingg mencapai 5 juta. Dari 14 temuan pembagian uang, 2 terlapor Sultan-Mujiono, 7 terlapor Ridwan-Rohidin dan 5 laporan yang tidak diketahui. Tingginya transaksi suara dengan menggunakan uang dianggap calon merupakan hal yang paling mudah untuk meraup suara. "membagikan uang kepada masyarakat yang mempunyai hak pilih kami anggap itu yang menjadi senjata ampuh untuk mendulang suara. Kami membutuhkan suara dan masyarakat kami yakin sangat membutuhkan uang. intinya simbiosis mutualism. pembagian uang kepada masyarakat kami atur secara sistematis, sehingga kami dapat memantau dan masyarakat yang mendapatkan uang harus dipastikan memilih kandidat kami" (Wawancara dengan Yaldensih, 22 Agustus 2017).

Banyaknya laporan terhadap pasangan Ridwan-Rohidin yang notabenenya pemenang Pilkada, mengindikasikan kekecewaan kubu pasangan Sultan-Mujiono. Laporan penggunaan politik uang secara massif dilaporkan ke Bawaslu setelah pemungutan suara dilaksanakan. Fenomena tersebut menjadi bukti kuat bahwa pelaporan praktik politik uang akan dilaporkan setelah ada hasil menang atau kalah. Keengganan untuk melaporkan politik uang pada saat kejadian berlangsung menjadikan alasan penulis berkesimpulan bahwa pelaporan tersebut hanya sebagai jalan untuk menganulir keputusan KPU.

Diantara pemilih yang bersikap pragmatis tersebut, adalah hal mustahil untuk mengurai praktik politik uang di setiap pemilihan umum. Keengganan 
untuk melaporkan kecurangan pelaksanaan Pilkada termasuk didalamnya praktik politik uang disebabkan karena beberapa hal. Pertama, sikap pragmatisme masyarakat yang karena kurangnya sosialisasi dari pelaksana Pilkada baik dari KPU maupun dari Baswaslu. Kedua, pihak-pihak yang terlibat dari proses penyebaran uang adalah orang yng terdekat dari pemilih, sehingga sulit untuk dilaporkan kepada panitia pengawas Pemilu.

Kinerja dari Bawaslu yang sudah gencar melaksanakan sosialisasi untuk mengurangi politik uang pada Pilkada Bengkulu ternyata tidak sesuai dengan ekspektasi. Buktinya, masih banyak praktik politik uang yang terjadi selama proses Pilkada. Sehingga menurut penulis, maraknya praktik politik uang disebabkan dua hal. Pertama, sosialisasi bawaslu yang belum massif dalam memberikan kesadaran politik kepada masyarakat untuk tidak terlibat baik secara aktif maupun pasif dalam praktik politik uang. Kedua, tingkat kesadaran masyarakat yang masih sangat rendah diakibatkan pragmatisme politikekonomi.

Faktor ekonomi juga turut menjadi penentu berkembang tidaknya politik uang. Dalam negeri yang cukup matang pertumbuhan ekonominya, maka sedikit ruang untuk politik uang dapat bekerja, misalnya di Amerika dan beberapa negara Eropa dengan tingkat pertumbuhan yang pesat. Berbeda dengan negara dengan tingkat pertumbuhan dan IPM yang rendah sebagai misal di negara dunia ketiga, antara lain di Indonesia dan Afrika sebagaimana penelitian Idowu (2013) di Negeria. Dengan tingkat pertumbuhan ekonomi yang relatif lamban dan IPM yang rendah menyebabkan tumbuh suburnya praktik politik uang.

Di Bengkulu menurut data Bappenas, dari 34 provinsi di Indonesia Indeks Pembangunan Manusia berada pada posisi 20 pada tahun 2015 dengan tingkat pertumbuhan ekonomi yang berada pada posisi 28 pada tahun 2014 . Provinsi Bengkulu juga merupakan provinsi dengan tingkat kemiskinan tertinggi di Pulau Sumatera. Artinya daerah dengan ekonomi yang rendah atau tingkat 
kemiskinan yang tinggi menjadikan praktik politik uang semakin subur. Ada pertautan antara kemiskinan dengan politik uang yang sangat kuat.

Bukan hanya uang yang menjadi alat transaksi suara, tetapi barang juga merupakan alat yang digunakan untuk melakukan transaksi antara kandidat dengan pemilih. Pada umumnya, kandidat mempunyai anggapan bahwa dengan pemberian barang tidak akan beresiko dan kandidat akan terhindar dari pelanggaran Pilkada. Banyak motif pemberian barang yang bisa menjauhkan dari kata pelanggaran. Pada dasarnya, setiap kandidat beranggapan bahwa pemberian barang merupakan hal yang wajar juga berlaku untuk pemilih. Sehingga dengan anggapan kewajaran diantara dua aktor tersebut semakin mempersubur praktik politik uang.

Pada Pilkada Provinsi Bengkulu, kain sarung merupakan barang yang paling banyak digunakan untuk transaksi suara. Pemilihan barang sebagai alat transaksi lebih dominan jika dibandingkan dengan penggunaan uang. "Pada pemilihan gubernur, baik calon nomor satu maupun calon nomor dua memberikan kain sarung dan peralatan shalat kepada calon pemilih, mungkin hampir semua Masyarakat Provinsi Bengkulu sudah merasakan yang namanya barang atau pemberian kandidat pada saat pemilihan gubernur kemarin, saya melihat itu benar-benar ada di masyarakat" (Wawancara dengan Ediansyah, 15 September 2017).

\section{Vote Trading: Keterlibatan Penyelenggara}

Pasangan Ridwan-Rohidin terbukti memberikan uang sebesar Rp 5 juta kepada anggota Panitia Pemilihan Kecamatan (PPK) Singaran Pati, bernama Ahmad Ahyan yang telah dijatuhi sanksi pemberhentian tetap oleh Dewan Kehormatan Penyelenggara Pemilu (DKPP). Kasus ini pun digugat oleh pasangan Sultan-Mujiono dan berakhir di meja Mahkamah Konstitusi, meskipun pada akhirnya kemenangan tetap berada di tangan Ridwan-Rohidin.

Faktor vote trading sangat mungkin terjadi, praktik kecurangan dalam 
Pemilu dengan sangat mudah dilakukan karena adanya konspirasi antara kandidat atau tim sukses dengan pihak penyelenggara Pemilu. Menguatnya praktik perdagangan suara yang melibatkan penyelenggara Pemilu sangat terkait dengan realitas sangat permisifnya para pihak terkait dengan proses penyelenggaran Pemilu. Pada Pilkada Provinsi Bengkulu didapatkan 2 laporan politik uang yang melibatkan pihak penyelenggara.

Kasus yang melibatkan Nismawati (Anggota Panwascam Singaran Pati) dengan dugaan pelanggaran Kode Etik a/n Ahmad Ahyan (anggota PPK Singaran Pati) yang telah mengundang Calon Gubernur Provinsi Bengkulu Ridwan Mukti dan menerima secara langsung uang Rp.5.000.000,- hasil lelang nasi punjung yang dimenangkan Ridwan Mukti pada acara Penutupan Kegiatan Perayaan 17 Agustus dan Pesta Rakyat Lembak. Bukan hanya itu, pelibatan penyelenggara lainnya juga adalah keterlibatan Apen Ardiansyah, SP (Anggota Panwas Kab. Kaur) dengan didapatnya amplop 130 buah berisi masing-masing uang Rp.20.000. Hal ini mengindikasikan bahwa vote trading juga menjadi strategi yang dijalankan kandidat selain memberikan uang atau barang secara langsung kepada pemilih. Atas dasar terjadinya praktek vote trading yang melibatkan oknum penyelenggara mengakibatkan integritasnya di mata masyarakat menjadi runtuh.

Keterlibatan pihak penyelenggara dalam transaksi politik uang mengindikasikan ketidakseriusan dalam menciptakan alam demokrasi yang subur di Provinsi Bengkulu. Sebagai misal, 2 contoh kasus keterlibatan penyelenggara dengan modus yang berbeda. anggota PPK yang mengundang salah satu kandidat dalam acara sekaligus menerima uang sebanyak 5 juta. Kedua, pelanggaran dugaan politik uang yang melibatkan Panwas Kabupaten Kaur. Jadi, keterlibatan pihak penyelenggara baik dari panitia pemilihan sampai panitia pengawas tidak bisa dielakkan lagi.

Dari dua temuan keterlibatan penyelenggara Pemilu dalam transaksi 
politik uang, maka modus yang digunakan adalah dengan bermain di PPK dan Panwas. PPK karena akan lebih memberikan efek perubahan suara yang lebih signifikan dibandingkan dengan membagikan per-individu. Praktik ini sangat potensial untuk menambah suara secara signifikan. Selain itu, untuk mengamankan praktik transaksi jual beli suara dengan panitia pemilihan maka langkah aman untuk distribusi ke masyarakat adalah melalui panitia pengawas. Panitia pengawas Pemilu sekaligus berperan ganda sebagai distributor untuk membantu kandidat dengan resiko tertangkap yang sangat rendah.

\section{Target Club Goods}

Jika sebelumnya telah dijelaskan dua bentuk politik uang di atas, antara lain vote buying dan vote trading maka ada satu lagi bentuk politik uang yang digunakan pada Pilkada Provinsi Bengkulu tahun 2015, yaitu club goods (barang kelompok). Sasaran kandidat dalam kategori yang terakhir ini adalah komunitas yang sudah terbentuk baik secara formal ataupun nonformal. Komunitas formal memiliki struktur organisasi dan kepengurusan seperti kelompok remaja masjid, komunitas gereja, majelis taklim, ikatan-ikatan kerukunan masyarakat, dll. Sedangkan untuk komunitas nonformal yaitu tidak memiliki struktur organisasi dan kepengurusan, seperti klub sepakbola, kelompok musik, komunitas hobi, dll.

Pemberian barang dalam bentuk kelompok dinilai efektif dan efesien untuk menghemat anggaran kandidat. Nilai efesiensi dapat dilihat misalnya, pemberian tenda kepada masyarakat sebuah dusun dengan memberikan garansi maksimal warga dusun tersebut untuk memilih. Dari sisi anggaran, kandidat diuntungkan dengan harga tenda dan biaya yang harus dikeluarkan apabila dibandingkan dengan membagikan uang persetiap kepala. "Bahkan ada juga yang mungkin bisa dikategorikan money politic tapi bentuknya lebih santun yaitu pasangan calon memberikan bantuan ke masjid dengan komitmen kalau masjidnya dibangun maka masyarakat di sana akan massif memilih pasangan 
calon, ada juga yang membangun jembatan rusak, membangun jalan dengan harapan dipilih pada Pilkada" (Wawancara dengan Ediansyah, 15 September 2017).

Secara umum yang menjadi target adalah kelompok karangtaruna dan PKK. Pemilihan kelompok karangtaruna dan kelompok PKK, karena kedua kelompok tersebut lebih aktif mengadakan kegiatan dalam kelompok mereka. Barang yang dibagikan kepada kelompok masyarakat tidak selalu sama dan dikondisikan dengan kebutuhan setiap kelompok masing-masing.

Dari uraian dan temuan peneliti di lapangan, secara sederhana bentuk politik uang terbagai atas 3 diantaranya vote buying, vote trading dan club goods. Untuk vote buying terdiri dari uang dengan nominal antara Rp 20.000 sampai 200.000, per kepala/KK, sedangkan untuk barang paling banyak dibagikan berupa sarung dan jilbab. Bentuk politik uang yang kedua adalah vote trading, terdapat 2 kasus keterlibatan penyelenggara (Panwascam Singaran Pati dan Panwaslu Kabupaten Kaur) ditambah 1 kasus PPK yang berakhir di meja Mahkamah Konstitusi. Besaran nominal mulai Rp. 2.600 .000 sampai Rp. 5.000.000. Ketiga, jenis politik uang club goods, pembagian barang kelompok kepada masyarakat yang tergabung dalam kelompok yang sasarannya adalah kelompok pemuda dan kelompok ibu-ibu. Barang yang dibagikan berupa kebutuhan dari kelompok tersebut.

\section{Tabel 5.5}

Ringkasan Jenis Politik Uang

\begin{tabular}{|l|l|c|l|}
\hline No & Jenis Politik Uang & Jumlah & \multicolumn{1}{|c|}{ Keterangan } \\
\hline 1 & Vote buying & 33 & $\begin{array}{l}\text { Laporan tidak ditindaklanjuti karena tidak } \\
\text { memenuhi syarat formal dan materil serta } \\
\text { kedaluwarsa }\end{array}$ \\
\hline 2 & Vote trading & 2 & $\begin{array}{l}\text { Telah melanggar UU no 5 tahun 2015 pasal } \\
54 \text { ayat (2) tentang kede etik, diteruskan ke } \\
\text { DKPP RI }\end{array}$ \\
\hline 3 & Clubgoods & 1 & $\begin{array}{l}\text { Laporan tidak ditindaklanjuti karena tidak } \\
\text { memenuhi syarat materil dan telah }\end{array}$ \\
\hline \hline
\end{tabular}

Journal of Governance and Local Politics (JGLP)

ISSN (online): 2684-9992, Vol: 1, Nomor: 1, Mei 2019 
\begin{tabular}{|l|l|l|l|}
\hline & & & kedaluwarsa \\
\hline
\end{tabular}

Sumber: Bawaslu Provinsi Bengkulu

Dari tiga jenis politik uang, vote buying merupakan modus yang paling banyak dilakukan, sebanyak 33 kasus, untuk vote trading sebanyak 2 kasus dan club goods sebanyak 1 kasus. Total laporan pelanggaran politik uang di Bawaslu Provinsi Bengkulu sebanyak 36 kasus. 35 diantaranya tidak ditindaklanjuti karena beberapa faktor, diantaranya tidak memenuhi syarat formal dan materil, kedaluwarsa karena jarak waktu temuan dan laporan terlalu jauh, tidak jelasnya pihak yang terlapor, dan tidak memenuhi 2 alat bukti.

Hanya 1 kasus yang ditindaklajuti sampai ke DKPP RI karena dinilai telah melanggar UU Nomor 5 Tahun 2015 pasal 54 ayat 2, Peraturan Bersama KPU, Bawaslu, DKPP No 13 Tahun 2012, No 11 Tahun 2012, No 1 Tahun 2012, Pasal 9 huruf g, Pasal 10 huruf a, c dan k, Pasal 14 huruf c. Pelanggaran kode etik. Kemudian pasangan Sultan-Mujiono melakukan gugatan ke Mahkamah Konstitsi lewat kasus tersebut. Meskipun MK akhirnya menolak gugatan tersebut berdasarkan pertimbangan ambang batas suara antara pemohon dan peraih suara terbanyak. Selisih diantara keduanya sebanyak 14\%, oleh karena itu permohonan pemohon tidak memenuhi syarat sebagaimana ditentukan UU Nomor 8 Tahun 2015 pasal 158.

Celah yang didapatkan dari UU Nomor 8 Tahun 2015 hubungannya dengan politik uang adalah meskipun dengan pelanggaran politik uang begitu massif dilakukan, namun jika selisih perolehan suara diatas 2\% maka tidak akan ditindaklanjuti. Hal tersebut tentu akan semakin mempersubur praktik politik uang pada Pilkada di Provinsi Bengkulu. Tentu data ini dapat dilihat dari banyaknya laporan pelanggaran politik uang di Bawaslu Provinsi Bengkulu. 


\section{KESIMPULAN}

Studi yang dilakukan di Bengkulu ini, menggambarkan begitu massifnya praktik politik uang pada saat momentum Pilkada dihelat. Beberapa bentuk politik uang ditemukan diantaranya vote buying, vote trading, dan club goods. Ada dua jenis vote buying yaitu dalam bentuk uang dan barang. Uang yang dibagikan mulai dari Rp. 20.000 sampai Rp. 200.000 per kepala/KK. Sedangkan barang yang dibagikan paling banyak berupa kain sarung. Kasus vote trading meyeret keterlibatan penyelenggara (Panwascam Singaran Pati dan Panwaslu Kabupaten Kaur) ditambah 1 kasus PPK yang berakhir di meja Mahkamah Konstitusi. Besaran nominal mulai Rp. 2.600.000-Rp. 5.000.000. sedangakan bentuk politik uang club goods yang pembagian barang kelompok kepada masyarakat yang tergabung dalam kelompok yang sasarannya adalah kelompok pemuda dan kelompok ibu-ibu, sesuai dengan kebutuhan dari setiap kelompok.

\section{REFRENSI}

Aswad. (2015). Kabupaten Kapuas: Peran Uang, Barang, dan Keluarga dalam Memenangkan Caelg dalam Edward Aspinal \& Mada Sukmajati (penyunting) Politik Uang di Indonesia, Patronase dan Klientelisme pada Pemilu Legislatif 2014. Yogyakarta: PolGov.

Azhari, A. A. (2012). Politik Uang dalam Pemilukada Kabupaten Mandailing Natal Tahun 2010. Dinamika Politik, 1(01).

Damanik, Ahmad Taufan. (2015). Medan, Sumatera Utara: Antara Politik Etnik dan Politik Uang dalam Edward Aspinal \& Mada Sukmajati (penyunting) Politik Uang di Indonesia, Patronase dan Klientelisme pada Pemilu Legislatif 2014. Yogyakarta: PolGov.

Idowu, C. A., \& Etinosa, E. M. (2013). Money Politics and Good Governance in Nigeria. International Journal of Social Sciences and Humanities Review, 4(2). 
BENTUK POLITIK UANG PADA PILKADA PROVINSI BENGKULU

Kumorotomo, W. (2009). Intervensi Parpol, Politik Uang Dan Korupsi: Tantangan Kebijakan Publik Setelah Pilkada Langsung.

Moleong, Lexy J. (2007). Metodelogi Penelitian Kualitatif (edisi revisi). Bandung:

PT. Remaja Rosdakarya.

Nasution, E. Perselingkuhan Antara Politik Dan Uang (Money Politics) Menciderai Sistem Demokrasi.

Zaman, Rambe Kamarul. (2016). Perjalanan Panjang Pilkada Serentak. Bandung: $\quad$ Expose (PT. Mizan Publika).

\section{Media Online}

Republika.co.id, 7 januari 2016

JJPN.com, 2016

Wawancara:

Wawancara dengan Ediansyah, 15 September 2017.

Wawancara dengan Yaldensih, 22 Agustus 2017. 